\title{
IMPLEMENTATION OF USING USED MATERIALS AND NATURAL MATERIALS AS LEARNING MEDIA IN IMPROVING COGNITIVE DEVELOPMENT
}

\author{
Khairuni Siregar ${ }^{1}$, Hafsah $^{2}$, Farida Jaya ${ }^{3}$ \\ State Islamic University of North Sumatra Medan, Indonesia \\ khairunisiregar@uinsu.ac.id ${ }^{1}, \underline{\text { hafsah@,uinsu.ac.id }}{ }^{2}$, faridajaya@,uinsu.ac.id ${ }^{3}$
}

Received: 02-08-2021 Revised: 18-10-2021 Accepted: 30-10-2021

\begin{abstract}
This article aims to describe the implementation of the use of used materials and natural materials as learning media in improving cognitive development at RA(kindergarten) Munawwarah Medan. The focus of the study described in this article includes the ability of teachers to design teaching materials sourced from natural and used materials, the learning process, and improving the cognitive competence of students. This study uses a qualitative approach with a descriptive method. The process of collecting data was carried out qualitatively by means of observation, interviews and document studies. Then, the data were analyzed through data reduction techniques, data presentation and drawing conclusions. The results of this article found that (1) the teacher's ability is fairly good in designing teaching materials sourced from natural and used materials, this is evidenced by the readiness of teacher learning plans; (2) the implementation of learning takes place effectively, marked by the suitability of the plans that have been made previously with the learning implementation process, as well as the process of learning activities using natural materials and used materials, starting from initial activities, core activities to closing activities; and (3) the cognitive competence of students at RA Munawwarah Medan is increasing well, marked by the child's ability to mention numbers, know the concept of numbers, be able to sort objects from smallest to largest, group objects according to type and color, and mention the function of an object.
\end{abstract}

Keywords: Natural Materials, Used Materials, Learning Media, Cognitive Development.

\begin{abstract}
Abstrak
Artikel ini bertujuan untuk mendeskripsikan implementasi penggunaan bahan bekas dan bahan alam sebagai media pembelajaran dalam meningkatkan perkembangan kognitif di $\mathrm{R} A$ Munawwarah Medan. Fokus kajian yang diuraikan dalam artikel ini meliputi kemampuan guru dalam mendesain bahan ajar yang bersumber dari bahan alam dan bahan bekas, proses pembelajaran, dan peningkatan kompetensi kognitif peserta didik. Penelitian ini menggunakan pendekatan kualitatif dengan metode deskriptif. Proses pengumpulan data dilakukan secara kualitatif dengan teknik observasi, wawancara dan studi dokumen. Kemudian, data dianalisis melalui teknik reduksi data, penyajian data dan penarikan kesimpulan. Hasil artikel ini menemukan babwa (1) kemampuan guru terbilang baike dalam mendesain bahan ajar bersumber dari bahan alam dan bahan bekas, hal ini dibuktikan dengan kesiapan perencanaan pembelajaran guru; (2) pelaksanaan pembelajaran berlangsung efektif, ditandai dengan kesesuaian perencanaan yang telah dibuat sebelumnya dengan proses pelaksanaan
\end{abstract}


pembelajaran, serta proses kegiatan pembelajaran menggunakan bahan alam dan bahan bekas, mulai dari kegiatan awal, kegiatan inti hingga kegiatan penutup; dan (3) kompetensi kognitif siswa di $\mathrm{R} A$ Munawwarah Medan meningkat dengan baik, ditandai dengan kemampuan anak menyebutkan bilangan angka, mengetahui konsep bilangan, mampu mengurutkan benda mulai dari terkecil sampai terbesar, mengelompokkan benda sesuai jenis dan warnanya, serta menyebutkan fungsi suatu benda.

Kata Kunci: Bahan Alam, Bahan Bekas, Media Pembelajaran, Perkembangan Kognitif.

\section{INTRODUCTION}

Education is an investment in life in the future. Efforts to preserve the earth and its contents, can be reached through education. Because educated people are a positive hope for better earth management and bring benefits. ${ }^{1}$ In line with this, Suyadi, et.al., explained that the purpose of education is to help children (students) to be able to independently develop their abilities and potential in order to understand life as a whole. ${ }^{2}$

The ability of children to develop at an early age is very large. Likewise, as educators, they should not separate children from learning from playing. Because, Mutiah explicitly stated that playing is a child's world. ${ }^{3}$ For this reason, through games, values, competence development, and creativity of children can be imprinted. ${ }^{4}$

According to Asmawati, connecting children to learn while playing requires exploration, planning, implementation, use of learning resources, learning media and game tools. ${ }^{5}$ In line with this, Sugiyono in Khadijah states that learning media is an intermediary for delivering messages, which plays a role in helping children understand and easily accept lesson content, so that learning is more effective and efficient. ${ }^{6}$ Furthermore, Aqib informed that the learning given to children should be designed with the help of educational game tools (APE) learning media.?

In relation to the above opinion, Zaman \& Eliyawati explained that through learning media, the classroom situation will be more conducive and active (live), helping students interact with teachers and learning resources, and in accordance with the way children learn. ${ }^{8}$ Furthermore, Karwono added that the use of media must consider the side of convenience and flexibility, including economical costs. ${ }^{9}$ For this reason, the use of nature (environment) can be used as an alternative in making learning media. Supporting this opinion, Hildayani added that in addition to using nature or the environment, learning media can also be made from used materials that can be re-created. ${ }^{10}$

\footnotetext{
${ }^{1}$ Dwi Siswoyo, Ilmu Pendidikan (Yogyakarta: UNY Press, 2013), 1.

${ }^{2}$ Suyadi, et.al., Konsep Dasar PAUD (Bandung: Remaja Rosdakarya, 2013), 1.

${ }^{3}$ Diana Mutiah, Psikologi Bermain Anak Usia Dini (Jakarta: Prenada Media Group, 2010), 4.

${ }^{4}$ Hartati Sofia, Perkembangan Belajar pada Anak Usia Dini Jakarta: Departemen Pendidikan Nasional,

${ }^{5}$ Luluk Asmawati, Perencanaan Pembelajaran PAUD (Bandung: Remaja Rosdakarya, 2014), 36.

${ }^{6}$ Khadijah, Media Pembelajaran Anak Usia Dini (Medan: Perdana Publishing, 2015), 13.

7 Zainal Aqib, Model-model Media dan Strategi Pembelajaran Kontekstual Inovatif (Bandung: Yrama Widya,

${ }^{8}$ Badru Zaman \& Cucu Eliyawati, Bahan Ajar Pendidikan Profesi Guru (PPG): Media Pembelajaran Anak Usia Dini (Bandung: Universitas Pendidikan Indonesia, 2010), 30.

${ }^{9}$ Karwono, Belajar dan Pembelajaran Serta Pemanfaatan Sumber Belajar, edisi Revisi (Jakarta: PT. Rajagrafindo Persada, 2012), 14.

${ }^{10}$ Rini Hildayani, Psikologi Perkembangan Anak (Jakarta: Universitas Terbuka, 2004), 27.
} 2012), 12. 2017), 17. 
Indeed, relevant research has been studied by many previous researchers. Among them are Sautele, et.al., who concluded that the use of media has a major impact on the effectiveness and efficiency of learning, even the weakness of teachers (less skilled) in conveying learning content, can be minimized by the presence of unique and creative media. ${ }^{11}$ Supporting previous research, Nurhidayah, et.al., also found that the use of natural (environmental) media can increase the creativity of early childhood (PAUD) children. ${ }^{12}$ Likewise, other research conducted by Sujarwo, found that used goods that had been thrown away in the trash can actually be used and recycled as creative learning media for early childhood. ${ }^{13}$

Based on the initial study that the researchers conducted at RA Munawwarah Medan Maimun, there were weaknesses in teaching teachers, namely in the aspect of using the surrounding environment as a learning medium. In addition, the information obtained from the teachers also admitted that they were not yet skilled in creating natural and used materials as learning media. On this basis, the researcher conducted an in-depth search on the use of learning media in RA, which was summarized in the title, "Implementation of the Use of Used Materials and Natural Materials as Learning Media in Improving Cognitive Ability in RA Munawwarah Medan".

\section{METHOD}

\section{Research Approach and Type}

This study uses a paradigm or a qualitative approach, with a descriptive method. ${ }^{14}$ The substance of the research which is fundamental to extracting the true meaning of the phenomena and facts of learning for early childhood at RA Munawwarah, is described in detail and systematically in this study.

Therefore, researchers play an active role in extracting information from informants through the interview process, coupled with the results of observations (observations) and document studies. The data obtained will be further analyzed through substantive data sorting techniques (data reduction), narrative data presentation starting from observations, interviews and documentation, as well as drawing objective conclusions by the researcher. As a result, the validity of this research is largely determined by the compatibility and firmness of the research data, tested through triangulation techniques, both method triangulation and research data source triangulation. ${ }^{15}$ Furthermore, the framework (research flow) can be seen in the chart (scheme) below:

${ }^{11}$ Eleanor Sautele, et.al., Resielence, Self Regulation and Cognitive Ability, Relevant to Teacher Selection, Journal of Teacher Education, 40(1), 2015. https://search.informit.org/doi/abs/10.3316/ielapa.080852592705061.

12 Nurhidayah, et.al., Penerapan Metode Bercerita Berbantuan Media Papan Flanel untuk Meningkatkan Kemampuan Berbicara di TK Kamila Singaraja, Jurnal PAUD Universitas Pendidikan Ganesha, 4(1), 2016. https://ejournal.undiksha.ac.id/index.php/JJPAUD/article/view/7806.

13 Sujarwo, Pengembangan Media Pembelajaran PAUD (Yogyakarta: SKB, 2008), 12.

14 Sudarwan Danim, Menjadi Peneliti Kualitatif (Bandung: Pustaka Setia, 2002), 35.

15 S. Nasution, Metodologi Penelitian Naturalistik Kualitatif (Bandung: Tarsito, 1996), 5. 


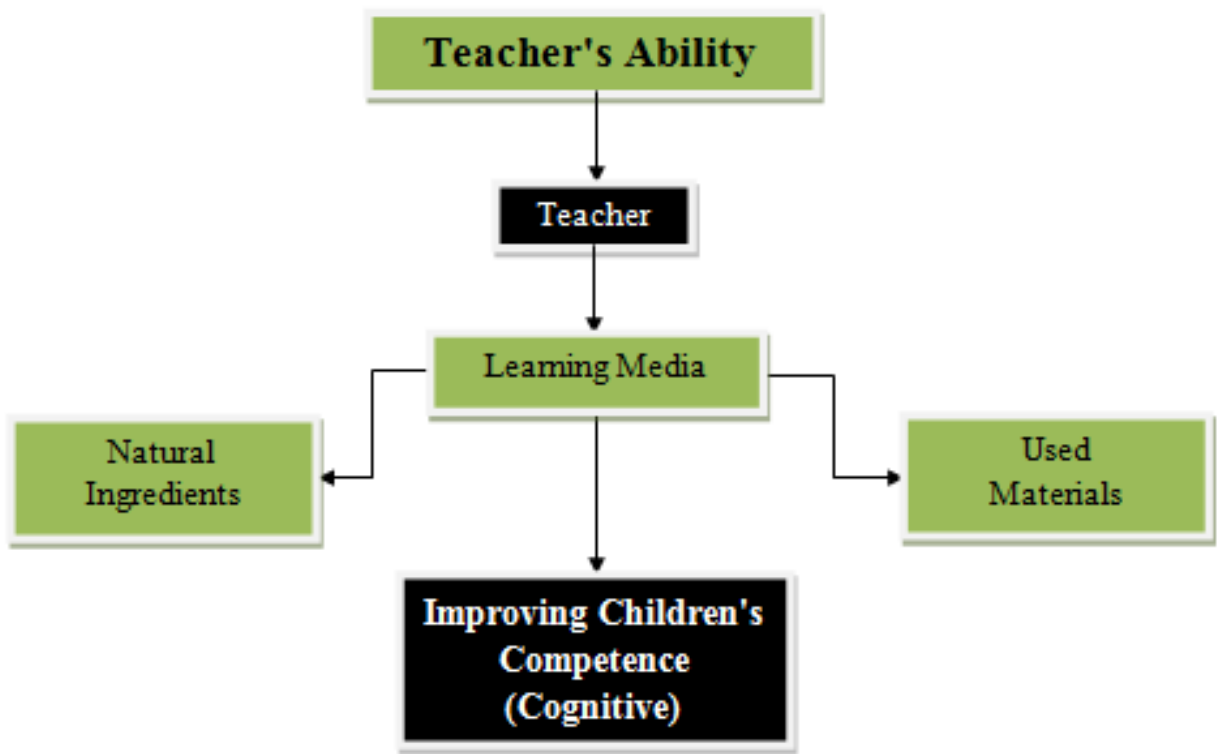

\section{Research Background}

Figure: 1. Teoretichal framework

This research was conducted at RA Munawwarah, which is located at Jalan Pasan Senen, Number 9 Kampung Baru, Medan Maimun, Medan City. This location is used as the background for the research based on the RA services provided according to the child's age level, namely 5-6 years, this RA is also known to have used natural materials and used materials as learning media. Thus, this place is suitable and relevant to the research topic. The research lasts a relatively long time, Semester I (odd) for the 2020-2021 school year, per month from August to December 2020.

\section{Data and Data Sources}

Data is real information or material that can be used as the basis for a study (analysis or conclusion). ${ }^{16}$ While the data source is the subject from which the data can be obtained. The data sources are people who can provide data through interviews, places that present views in the form of stillness (eg rooms, objects, etc.) and motion (eg activities, performance, teaching and learning activities, etc.), as well as symbol (paper) that presents a sign in the form of letters, numbers or other symbols. ${ }^{17}$

The data and data sources are divided into two, namely as follows: 1) Primary data is data that is directly obtained from the first data source of research or research object. ${ }^{18}$ Primary data is data taken directly from the researcher to the source, without any intermediary. According to Sugiyono revealed that primary data is a direct source of data from providing data to data or data taken directly from researchers to the source, without any intermediaries. ${ }^{19}$ The main source of this research is the teacher. 2) Secondary data is data obtained from a second source that is not directly related to the object or from this research, the material is expected to complement and clarify the primary data. ${ }^{20}$ Meanwhile, according to Sugiyono, secondary data is a source that does not directly provide data to data collectors

16 Wahid Murni, Cara Mudah Menulis Proposal dan Laporan Penelitian Lapangan Pendekatan Kualitatif, Skripsi, Tesis, dan Disertasi (Malang: UM Press, 2008), 41. See also Muhammad Shaleh Assingkily, Penelitian Tindakan Kelas: Meneliti dan Membenabi Pendidikan dari Kelas (Medan: CV. Pusdikra Mitra Jaya, 2021), 27.

${ }_{17}$ Suharsimi Arikunto, Prosedur Penelitian Suatu Pendekatan Praktik (Jakarta: Rineka Cipta, 2007), 107.

18 Burhan Bungin, Metodologi Penelitian Kuantitatif (Jakarta: Prenada Media Group, 2005), 132.

${ }^{19}$ Sugiyono, Metodologi Penelitian Kuantitatif, Kualitatif \& RnD (Bandung: Alfabeta, 2016), 266.

${ }^{20}$ Bungin, Metodologi Penelitian. 
or supporting references, as complementary materials needed in a researcher. ${ }^{21}$ This secondary data is the head of RA and students of RA Munawwarah Medan.

\section{Data collection technique}

Data collection techniques are the most strategic step in research, because the main purpose of research is to obtain data. ${ }^{22}$ Without knowing the data collection techniques, researchers will not get data that meets the data standards set. The data collection technique in this study is to use document review techniques as the main data collection technique. By using interview techniques as a supporting technique to obtain other data that supports the main data.

\section{Data Analysis Procedure}

After the data is collected, the data is analyzed to obtain conclusions from these data as well as to answer the formulation of the problem that has been compiled. ${ }^{23}$ There are three kinds of activities in analyzing qualitative data, namely: Data reduction is defined as the process of selecting, focusing and simplifying and transforming the raw data that appears in written notes in the field. Data reduction is part of the analysis, meaning that it continues as long as a qualitatively oriented project takes place. ${ }^{24}$ During data collection, there was a further reduction stage by selecting the data, namely the researchers' choices about which part of the data to use, which to summarize, which to classify in a broader pattern, and which data to discard. This continued until after the field research, until a complete final report was prepared. $^{25}$

Likewise, in this study, the researcher selects any data collected that is sourced from the teacher, head of RA and students, and adds relevant studies sourced from scientific articles and books by selecting and retrieving data that can support research, then researchers discard data that is not necessary, then summarize it in such a way that it can be developed in a broader pattern.

The second important flow of analysis activity is data presentation. Presentation is a structured collection of information that gives the possibility of drawing conclusions and taking action. The most frequently used presentation of qualitative data is in the form of narrative text. In fact, it is possible that the data will be presented in the form of tables, charts and graphs, all of which are designed to combine information arranged in a coherent form, so that an analyst can draw appropriate conclusions. ${ }^{26}$ Likewise, in this study, after data reduction was carried out on the data obtained, the researcher would present it in the form of narrative text in the form of data from interviews, observations and document studies.

The third important analytical activity is drawing conclusions and verification. The conclusion is part of the complete configuration. Conclusions were also verified during the study. The verification may take the form of a brief thought by the researcher while writing, a review of field notes, or by reviewing and brainstorming with peers or by extensive attempts to place a copy in another data set. In short, the meanings that emerge from the data must be tested for their correctness, robustness, and suitability, which is their validity. If so, then something true and clear will be obtained. ${ }^{27}$

\footnotetext{
${ }^{21}$ Sugiyono, Metodologi Penelitian, 222.

22 Sugiyono, Metodologi Penelitian, 104.

23 Abbas Tashakkori \& Charles Teddie, Mixed Methodology: Mengkombinasikan Pendekatan Kualitatif dan Kuantitatif (Jakarta: Pustaka Pelajar, 2010), 208.

${ }^{24}$ Matthew B. Milles \& A Michel Huberman, Analisis Data Kualitatif tentang Metode-metode Baru, Terj. Tjetjep Rohidi (Jakarta: Universitas Indonesia Press, 2009), 16.

${ }^{25}$ Milles \& Huberman, Analisis Data Kualitatif.

${ }^{26}$ Milles \& Huberman, Analisis Data Kualitatif, 17.

${ }^{27}$ Milles \& Huberman, Analisis Data Kualitatif, 18-19.
} 
Likewise, in the case of this study, after all data is reduced and presented, the researcher will draw conclusions from the results of the analysis of the implementation of the use of natural materials and used materials as learning media in improving students' cognitive abilities at RA Munawwarah Medan. Researchers also try to conduct verification by reviewing other documents, as well as discussing with more experts and colleagues to get correct and useful conclusions in accordance with the research objectives.

\section{RESULTS AND DISCUSSION}

\section{Teacher's Ability in Designing Learning Media From Natural Materials and Used Materials at RA Munawwarah Medan}

Based on the results of observations, it is known that the readiness of teachers in designing learning media at RA Munawwarah Medan is fairly good. This is indicated by a planned learning reference that is guided by the Daily and Weekly Learning Implementation Plan (RPPH/RPPM) which has been agreed upon by the teacher at the beginning of the semester.

According to the explanation from Guru RA Munawwarah, the preparation of the $\mathrm{RPPH} / \mathrm{RPPM}$ was adjusted to the ongoing theme and in accordance with the RA curriculum. Likewise, the media that is prepared, comes from the nature (environment) around the students, for example, such as making headbands with jackfruit leaves and sticks that are shaped like a headband. The process that the researchers observed, in which the teacher cleaned the jackfruit leaves themselves to prevent sap, then asked the students to sort the jackfruit leaves from the smallest to the largest, then the teacher helped the students make the jackfruit leaves and sticks into a circle like a headband, so that the students were very enthusiastic and happy to learn to make the headband.

The results obtained by the researchers related to the ability of teachers to design learning media made from natural and used materials in accordance with the RPPH, can be seen in table 1.

Table 1. Teacher Assessment Results in RPPH Preparation and Media Utilization

\begin{tabular}{clll}
\hline No. & \multicolumn{1}{c}{ Name } & Rating Score (\%) & \multicolumn{1}{c}{$\begin{array}{c}\text { Competency } \\
\text { Results }\end{array}$} \\
\hline 1. & Indah Umi Nadrah T., S.Ag & $94,64 \%$ & 4 (Very good) \\
\hline 2. & Aslam Mr Siregar & $91,71 \%$ & 4 (Very good) \\
\hline 3. & Nazla & $93,75 \%$ & 4 (Very good) \\
\hline 4. & Maysarah & $94,64 \%$ & 4 (Very good) \\
\hline 5. & Hayatun Mardiah & $73,21 \%$ & 3 (Good) \\
\hline 6. & Nelly & $72,72 \%$ & 3 (Good) \\
\hline 7. & Filma Daniyusa & $92,85 \%$ & 4 (Very good) \\
\hline 8. & Sri Banun Nst & $75,00 \%$ & 3 (Good) \\
\hline & & &
\end{tabular}


Table 2. Teacher Assessment Results in RPPH Preparation and Media Utilization

\begin{tabular}{cccc}
\hline No. & Category & Frequency & Percentage \\
\hline 1. & Very Good (Score 4) & 5 & $62,5 \%$ \\
\hline 2. & Good (Score 3) & 3 & $37,5 \%$ \\
\hline 3. & Pretty good (Score 2) & 0 & $0 \%$ \\
\hline 4. & Not good (Score 1) & 0 & $0 \%$ \\
\hline & Total & 8 & $100 \%$ \\
\hline
\end{tabular}

Based on tables (1) and (2) above, it can be understood that the ability of teachers in preparing RPPH related to designing learning media, 5 teachers have very good abilities with a percentage of $62.5 \%, 3$ teachers have good abilities with a percentage of $37.5 \%$. Thus, it can be concluded that the average teacher at RA Munawwarah Medan is very good in compiling the RPPH and the use of learning media, especially using natural (environmental) materials and used materials in accordance with the RPPH and learning themes.

Regarding the teacher's ability to design learning media, the results of an interview with one of the teachers were obtained, the following is an excerpt from the interview:

"We, the teachers, design learning media by preparing the RPPM and RPPH at the beginning of the semester together and then checking them out by the principal. When the teaching and learning activities started the day before, we prepared learning media according to the ongoing theme. We use media that comes from used materials or natural materials that exist in the surrounding environment, both the school environment and the student's home environment, of course, cooperation with the parents of students is needed here. ${ }^{128}$

In line with the interview above, Sri Banun said that:

"I as an educator or teacher in designing a learning media at Raudhatul Athfal Munawwarah Medan, of course we have to know and make first the prota and process in the school year and then make a Weekly Learning Implementation Plan (RPPM) from the curriculum then from this RPPM an Implementation Plan is made Daily Learning (RPPH), After that, the next step is to select and prepare learning media from the RPPH in accordance with the theme at the time that we will teach the students. The learning media that we prepare, if possible, are three-dimensional, meaning that they can be seen, touched and felt by children or actual objects. It's not just a picture. These objects, if possible, are objects that are around the child's life environment so that they can generate high interest, motivation, curiosity in children in learning with enthusiasm and not boring. ${ }^{129}$

Observing the interview excerpt above, it is understood that the manufacture of learning media through natural materials is intended for the surrounding environment, while used materials are materials in the trash that are still fit for use to be re-created. Furthermore, Mrs. Mardiah detailed the steps she applied in making learning media, along with excerpts from her interview:

"The steps I took in designing learning media both from natural and used materials were as follows: 1) Preparing RPPM and RPPH at the beginning of the semester 2). Determine the RPPH according to the ongoing theme. 3) Prepare learning media according to the theme by using materials

${ }^{28}$ Hasil wawancara dengan Ibu Sarah, Guru Kelas di RA Munawwarah, tanggal 03 Oktober 2020.

${ }^{29}$ Hasil wawancara dengan Ibu Sri Banun, Guru Kelas di RA Munawwarah, tanggal 05 Oktober 2020. 
from natural or used materials. 4) Prepare the materials needed by utilizing natural materials or used materials. 5) Make learning media that comes from natural materials or used materials according to the theme. When teaching and learning activities take place the teacher involves children to participate in making the learning media. This is where the teacher needs to explain the rules of the game in using tools or materials so that safety is maintained because children's behavior cannot be predicted. ${ }^{130}$

In line with the above, Mrs. Nelly said that:

"We, the teachers, have prepared the RPPM and RPPH at the beginning of the semester which are discussed together with the teachers here, each giving suggestions and then being examined by the principal. When learning has been running according to predetermined themes, we prepare learning media that are tailored to the theme given that the media together with the teacher come from natural and used materials. We make it first and then we prepare it for the children when the teaching and learning activities take place we give examples to the children first then the children work on it together. Involving children in this activity provides opportunities for children to develop cognitively, providing new experiences for children. ${ }^{31}$

Elaborating the results of the interviews above, it can be synthesized that there are several things that need to be considered in the use of learning media from natural and used materials, namely as follows: 1) The learning media used can convey learning material that will be delivered to students. 2) Learning media both derived from natural materials and used materials are easy to find and safe to use. 3) Paying attention to aspects of student development. 4) Provide fun and experience for students. 5) Adding new knowledge for students

Of course, in designing a learning media and making it a learning medium, a teacher is required to have expertise and experience. This is where the professionalism of a teacher is needed. How learning materials can be conveyed to students well so that the development goals of students, especially early childhood can be achieved properly.

The idea of producing learning media either from used materials or natural materials needs to be developed by the teachers at Raudhatul Athfal Munawwarah Medan. Based on the results of interviews with teachers at Raudhatul Athfal Munawwarah Medan in this case are as follows:

"Usually, I and other teachers share ideas or share in solving problems regarding early childhood learning media in this school. Ideas can come from anywhere, we can meet through colleagues, school environment. Moreover, sharing with more experienced teachers in this school and with the principal. ${ }^{\prime 2}$

In designing learning media and making it into a good medium from natural material media or used material media at Raudhatul Athfal Munawwarah Medan there are factors that hinder its implementation, following are the results of interviews with teachers Raudhatul Athfal Munawwarah Medan:

\footnotetext{
${ }^{30}$ Hasil wawancara dengan Ibu Hayatun Mardiah, Guru Kelas di RA Munawwarah, tanggal 07 Oktober 2020.

${ }^{31}$ Hasil wawancara dengan Ibu Nelly, Guru Kelas di RA Munawwarah, tanggal 08 Oktober 2020.

32 Hasil wawancara dengan Ibu Sarah, Guru di RA Munawwarah, tanggal 03 Oktober 2020.
} 
"One of the obstacles I face in making learning media derived from natural and used materials is my lack of ability and lack of knowledge, then time is limited due to the current COVID-19 pandemic, the learning time is less than usual and we have to make the best of it. ${ }^{133}$

The same thing was conveyed by teacher Raudhatul Athfal Munawwarah Medan on another occasion, namely:

"If the obstacles I face in making learning media that come from natural materials and used materials, especially at this time during the COVID-19 pandemic, it is certainly a matter of a very short time to study and maybe a problem with my insight to find ideas in using used materials. and natural materials as learning media." ${ }^{34}$

While the results of interviews with other teachers Raudhatul Athfal Munawwarah Medan are as follows:

"The obstacle that I feel in making learning media from natural and used materials is the lack of teacher creativity in making these media. I realize that the factor that becomes an obstacle in making this learning media is that I myself feel less creative.

Meanwhile, according to teacher Raudhatul Athfal Munawwarah Medan on another interview opportunity as follows:

"The obstacle in making learning media derived from used and natural materials apart from the lack of creativity from the teacher is the factor of the students who have different aspects of interest, motivation, intelligence. This is where the teacher's ability is required to be able to understand the situation so that the learning media used can be used for the overall development of students. ${ }^{136}$

After we know the obstacles faced by the solutions applied to overcome these obstacles, we can find out through the following interviews:

"Well, the solution that I did to overcome these obstacles was to continue to study and attend trainings organized by the Raudhatul Athfal Teachers Association (IGRA) or similar professional organizations, or ask directly with other Raudhatul Athfal teachers and along with the development today's advanced technology, I can learn through YouTube. While the solution for the limited time that exists during this covid period, we usually divide the children into several groups so that the short time can be used as well as possible. "'B7

In line with the statement above, the same thing was also conveyed by teacher Raudhatul Athfal Munawwarah Medan in other interviews, namely as follows:

"To overcome this problem, especially during the COVID-19 pandemic, namely the problem of limited learning time, which was carried out during the COVID-19 pandemic, it was carried out in waves or using the term shift. Children were divided into two time groups each one and a half hours long. So that learning materials can be delivered to children properly by preparing appropriate learning media. And regarding the issue of insight into creating or finding ideas for learning media, both from natural materials and used materials, you can work together with other classroom teachers, share with each other, or consult, learn through YouTube, participate in training training related to making learning media. ${ }^{138}$

\footnotetext{
${ }^{33}$ Hasil wawancara dengan Ibu Hayatun Mardiah, Guru Kelas di RA Munawwarah, tanggal 07 Oktober
} 2020.

${ }^{34}$ Hasil wawancara dengan Ibu Indah Umi Nadrah, Guru Kelas di RA Munawwarah, tanggal 18 Oktober 2020.

${ }^{35}$ Hasil wawancara dengan Ibu Filma, Guru Kelas di RA Munawwarah, tanggal 15 Oktober 2020.

${ }^{36}$ Hasil wawancara dengan Ibu Nazla, Guru Kelas di RA Munawwarah, tanggal 22 Oktober 2020.

${ }^{37}$ Hasil wawancara dengan Ibu Indah Umi Nadrah, Guru Kelas di RA Munawwarah, tanggal 23 Oktober 2020.

${ }^{38}$ Hasil wawancara dengan Bapak Aslam, Guru Kelas di RA Munawwarah, tanggal 28 Oktober 2020. 
Meanwhile, according to Mrs. Nazla, teacher Raudhatul Athfal Munawwarah Medan, solutions that can be done in overcoming obstacles in making learning media are as follows:

"I try to keep learning and keep learning because learning has no limits. Lifelong learning. This can be done by attending seminars, training, asking colleagues, exchanging ideas. If it is done will add knowledge and insight for us. "'39

Meanwhile, the results of interviews obtained from the Head of Raudhatul Athfal Munawwarah Medan regarding the solutions carried out in dealing with the obstacles faced in making learning media are as follows:

"I always motivate teachers to continue to be creative and innovate in making learning media. Sharing each other with the teacher in deliberation together can come up with ideas that are suitable for making learning media, sharing knowledge and experiences. Provide opportunities for teachers to attend seminars, training related to media creation." $\$ 0$

Based on the description of the interview above, it is understood that the obstacles felt by the teacher of RA Munawwarah Medan in making learning media come from natural (environmental) materials and used materials, including (1) the low creativity of teachers in the use of used materials and natural materials as preparation for making learning Media; (2) the difficulty of the teacher in designing the RPPH that is appropriate between the topics, material themes, and media used; (3) the factors of interest and motivation of children's intelligence are different.

\section{The Learning Process Implemented by Teachers Using Learning Media from Natural Materials and Used Materials at RA Munawwarah Medan}

Teaching and learning activities carried out at Raudhatul Athfal Munawwarah Medan cannot be separated from the role of the teacher. The ability of teachers is demanded well so that the learning process can run well too. The use of learning media derived from natural materials and used materials in the learning process greatly affects the learning process, where learning media is a means for teachers to deliver learning materials to students. The learning process using learning media from natural materials and used materials at RA Munawwarah Medan, the results of the assessment of the teacher's implementation in the learning process, and the teacher's ability to carry out the learning process can be observed in tables (3) and (4) below:

Table 3. Assessment Results on the Implementation of the Learning Process Conducted by Teachers

\begin{tabular}{clcl}
\hline No. & \multicolumn{1}{c}{ Name } & Rating Score (\%) & \multicolumn{1}{c}{$\begin{array}{c}\text { Competency } \\
\text { Results }\end{array}$} \\
\hline 1. & Indah Umi Nadrah T., S.Ag & $91,93 \%$ & 4 (Very good) \\
\hline 2. & Aslam Mr Siregar & $83,87 \%$ & 4 (Very good) \\
\hline 3. & Nazla & $82,25 \%$ & 4 (Very good) \\
\hline 4. & Maysarah & $83,06 \%$ & 4 (Very good) \\
\hline 5. & Hayatun Mardiah & $73,38 \%$ & 3 (Good) \\
\hline
\end{tabular}

${ }^{39}$ Hasil wawancara dengan Ibu Nazla, Guru Kelas di RA Munawwarah, tanggal 22 Oktober 2020.

${ }^{40}$ Hasil wawancara dengan Bapak Amri Munte, Kepala RA Munawwarah, tanggal 27 Oktober 2020. 


\begin{tabular}{clll}
\hline 6. & Nelly & $75,00 \%$ & 3 (Good) \\
\hline 7. & Filma Daniyusa & $81,45 \%$ & 4 (Very good) \\
\hline 8. & Sri Banun Nst & $74,19 \%$ & 3 (Good) \\
\hline
\end{tabular}

Table 4. Teacher's Ability in the Implementation of Learning

\begin{tabular}{cccc}
\hline No. & Category & Frequency & Percentage \\
\hline 1. & Very good (Score 4) & 5 & $62,5 \%$ \\
\hline 2. & Good (Score 3) & 3 & $37,5 \%$ \\
\hline 3. & Pretty good (Score 2) & 0 & $0 \%$ \\
\hline 4. & Not good (Score 1) & 0 & $0 \%$ \\
\hline & Total & 8 & $100 \%$ \\
\hline
\end{tabular}

Based on tables (3) and (4) above, it can be understood that the ability of teachers to carry out learning with the help of media made from natural and used materials, namely, 5 teachers have very good abilities with a percentage of $62.5 \%, 3$ teachers have the ability good with a percentage of $37.5 \%$. So, it can be concluded that the average teacher at RA Munawwarah Medan is very good in carrying out the learning process using learning media, especially using natural (environmental) materials and used materials.

This is in accordance with the interview conducted with the head of RA Munawwarah as follows:

"The teachers carry out the learning process in accordance with the RPPH that has been prepared in advance and learning media that are in accordance with the learning materials. The teacher starts the learning activities by conducting opening activities, core activities and closing activities. The use of natural or used learning media is adjusted to the learning material." ${ }^{, 1}$

The same thing was also conveyed by the teacher Raudhatul Athfal Munawwarah Medan in terms of the learning process at Raudhatul Athfal Munawwarah:

"In the learning process we do every day starting with opening activities, core activities and closing activities. In this core activity, we use learning media as a means of delivering learning materials to students, we prepare learning media both from natural materials and used materials. Then when learning takes place, we usually involve children in making or using it. As in the theme: My Environment, My Home, Sub-theme How to Take Care of Household Appliances, there is an activity of meronce on a plate drawing pattern. The meronce activity uses used materials, namely colorful mineral bottle caps. Before the meronce activity was carried out, the children were asked to group the bottle caps according to their color. There are 3 colors of bottle caps, namely blue, brown and green. After the children group the bottle caps according to their color, then work on the ronce on the plate image pattern by sorting the colors, namely green, blue and brown. The teacher first gave an example of how to do it, after that the children worked on their respective worksheets." ${ }^{* 2}$

${ }^{41}$ Hasil wawancara dengan Bapak Amri Munte, Kepala RA Munawwarah, tanggal 08 November 2020.
${ }^{42}$ Hasil wawancara dengan Bapak Aslam, Guru Kelas di RA Munawwarah, tanggal 12 November 2020. 


\section{Improving Children's Cognitive Competence in the Learning Process Assisted by Learning Media from Natural and Used Materials at RA Munawwarah Medan}
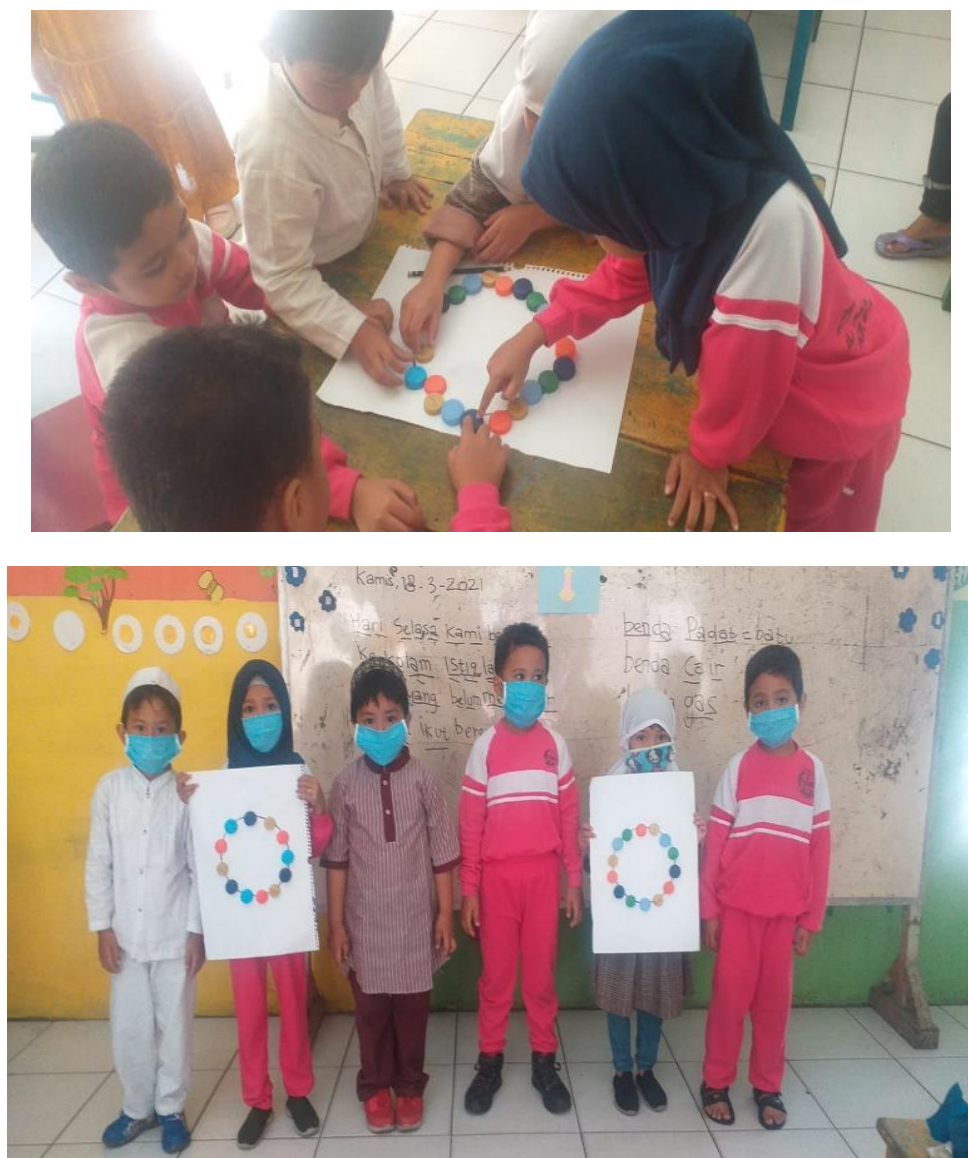

Figure 2. Meronce with an old mineral water bottle cap, previously the children grouped the BOTTLE LIDS BY COLOR (COGNITIVE DEVELOPMENT).

In interviews with other teachers at Raudhatul Athfal Munawwarah Medan, information was also obtained on how the learning process uses learning media made from natural and used materials as follows:

"When teaching and learning activities are carried out there are three parts that we do, namely opening activities, core activities, and closing activities. In the use of learning media, both using natural materials and used materials, it is adjusted to the material to be delivered, in practice the teacher usually first gives examples to students, then students do the tasks given by the teacher to explain the material so that students gain new knowledge and experience." "3.

In an interview with teacher Raudhatul Athfal Munawwarah regarding the learning process using learning media derived from natural materials and used materials are as follows:

"The learning carried out at Raudhatul Athfal Munawwarah consists of opening, core activities and closing activities. Such as learning activities on the theme of the sakinah family. The sub-theme of the profession of family members, the sub-theme of the pilot. The lesson is I. The opening is 30 minutes. Starting at 08.00-09.00 which contains activities, namely we invite children to say greetings, then read the syahadatain together, read prayers led by one of the children appointed by the teacher, read short suras, read $\mathrm{R} A$ Munawnarah's pledge, read thayyibah sentences, read Asmaul Husna, read prayers a day, such as prayers for going to sleep, getting up from sleep, praying for parents and so on. Sing together according to the theme such as the song umi and abi because the theme is about family.

\footnotetext{
${ }^{43}$ Hasil wawancara dengan Ibu Filma, Guru Kelas di RA Munawwarah, tanggal 14 November 2020.
} 
Introducing the hadith about cleanliness in the family, reading iqra privately then telling about today's theme. II. Core activities, after the opening activities, we then entered the core activities. The sub-theme is the family profession, namely pilot. The teacher shows a pilot picture of the children observing the picture. The teacher then asked which of the students had family members who worked as pilots and who had dreams of becoming a pilot. Then we (the teacher) told the children that today we are going to build an airplane driven by a pilot from used ice cream sticks. The teacher shows the ingredients which consist of: ice cream sticks, glue. When in the implementation of making the plane, the teacher must still be supervised. The teacher takes 7 ice cream sticks and then arranges them evenly and glues them one by one. Then take 2 ice cream sticks for the front of the plane and glue the top and bottom. Then take 1 ice cream stick and then cut it in half using a knife to cut this is done by the teacher and then affixed to the back as the tail of the plane. After that, the teacher asked the children to make an airplane as shown in the example. Before making the plane, the child was asked to count the number of sticks used to make the plane. The children counted the number of sticks with great enthusiasm. After they finished counting the number of sticks and together they made the plane with a happy and cheerful heart. Children can count the number of sticks shown by the teacher with variations in the number. When shown 5 sticks they immediately said the number five, when shown the stick with the number 9 they together counted the number with enthusiasm. III. The closing activity contains activities that ask how the students feel during the lesson, what are the activities today, ask about the profession of pilots and planes made from ice cream sticks and ask the number of sticks used in the manufacture of the plane. This is called a recalling activity, then inform tomorrow's activities. Then the activity was closed by reading a prayer after studying and greeting. That's the learning activity that we do. As a motivator, a teacher must continue to motivate students to continue to be enthusiastic in learning. ${ }^{44}$

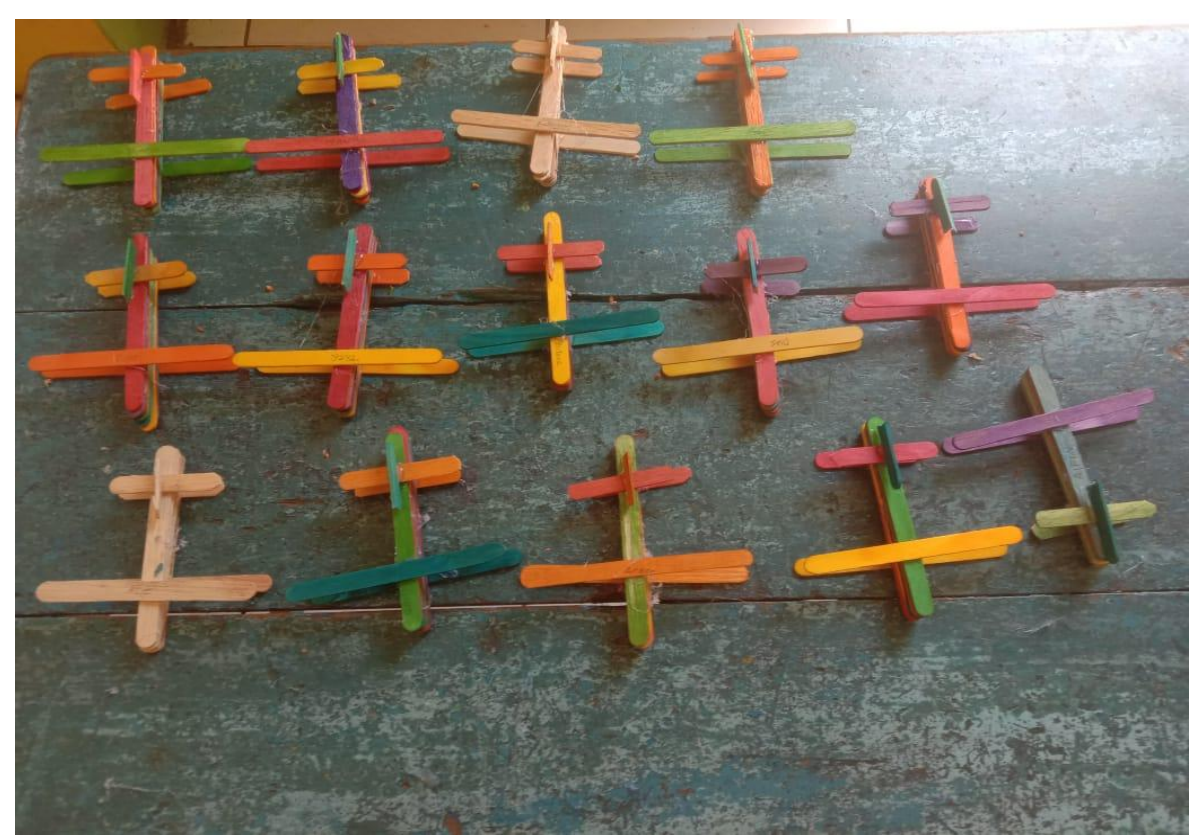

Figure. 3: The activity of counting the number of ice cream sticks (Cognitive Development) is followed by making an airplane from ice cream sticks

44 Hasil wawancara dengan Ibu Indah Umi Nadrah, Guru Kelas di RA Munawwarah, tanggal 14 November 2020. 
The learning process carried out at Raudhatul Athfal Munawwarah Medan, of course, the teacher plays an important role. How a teacher must be able to convey learning material so that students can easily capture the learning given. The expertise of a teacher is needed in this case.

On another occasion, information was obtained from one of the teachers at Raudhatul Athfal Munawwarah Medan about the learning process carried out by the teacher using learning media made from natural and used materials as follows:

"Every day the learning process that takes place in schools is carried out in accordance with the Daily Learning Implementation Plan (RPPH). The process of implementing learning begins with initial activities, continues with core activities and ends with closing activities. In today's core activity, the media used is natural material, namely grains. The theme of the lesson is Sakinah Family, sub-theme of Family Members, sub-sub-theme of Cousins. The activity carried out is a collage of sunflower pictures. Flowers planted by cousins. This collage uses seeds consisting of green beans, red beans and corn seeds. I gave the seeds and a plate for the child to put or group the grains according to color. After the children managed to group the seeds according to their color, they continued by working on a sunflower collage on the paper provided by the teacher using glue as a tool to glue them. The next activity is a closing activity, in this activity the teacher usually asks the child's feelings during learning, then asks again the lessons that have been given earlier. The teacher also informs the activities that will be carried out tomorrow then together read a prayer to go home. ${ }^{145}$

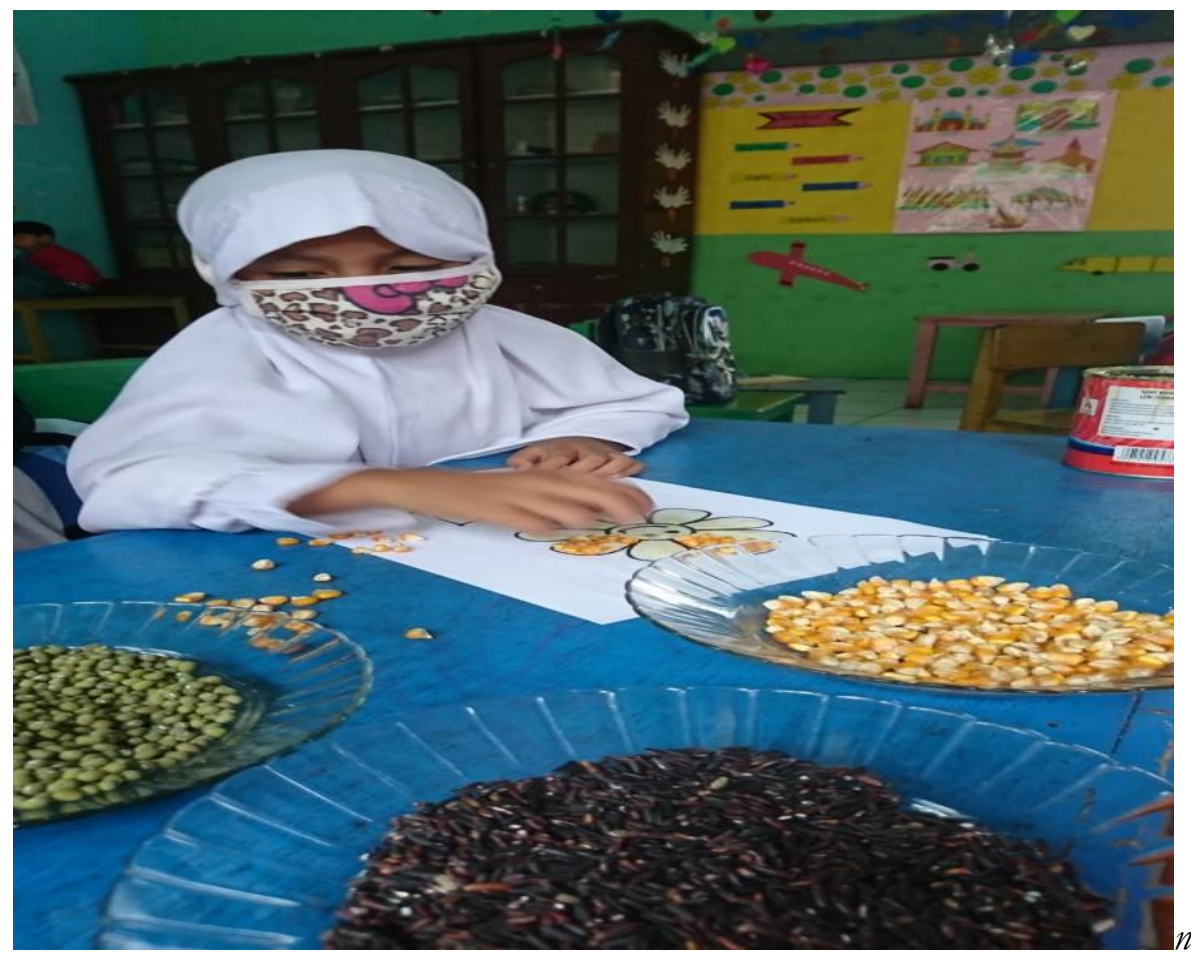

Figure 4: The activity of grouping grains according to color (cognitive development) followed by filling out patterns/collages of flower pictures

The results of interviews about the process of implementing learning carried out by teachers using learning media from natural and used materials are as follows:

"The learning process at Raudhatul Athfal Munawwarah begins with an opening activity: saying greetings then we read a prayer to learn, followed by reading short surahs together, even if there are

${ }^{45}$ Hasil wawancara dengan Ibu Sarah, Guru Kelas di RA Munawwarah, tanggal 15 November 2020. 
additional short surahs in this initial activity, we give them to the children, then sing together. After that the Iqra reading activity. Next we enter the Core Activities. In this activity, we begin to explain what the theme is going on, for example today the theme is: My Environment Sub-Theme of My House Sub-Theme of the Function of the House The teacher shows a picture of the house and then explains about the house and its function. Next, the teacher shows the students how to make a house from used cardboard. The teacher prepares the materials consisting of used cardboard, scissors, and glue. After the teacher shows how to make it then the teacher instructs the children to work on it together. when the work is done the children are very happy because they are directly involved in making the media. When finished they are happy to show the results of their work. From the learning media they did with the children, they dig up information about the function of the house. Children are able to properly name the function of the house in accordance with today's learning objectives. Then we entered the closing activity. In the closing activity, usually we teachers ask the children's feelings today then ask again what material we have learned and convey information about tomorrow's activities and then end with praying together before going home." $" 46$

From the results of observations made in the learning process using learning media with natural materials and used materials at Raudhatul Athfal Munawwarah Medan are as follows:

"The ability of teachers Raudhatul Athfal Munawwarah Medan in the learning process that is carried out every day shows that they prepare themselves as well as possible. They prepare learning media in accordance with the learning materials to be delivered which are contained in the RPPM and $\mathrm{RRPH}$. The learning process begins with the opening activity by starting with reading a prayer before studying then reading Surah Al Fatibah and short surahs, santri pledges, introduction to Asmaul Husna, pearls of hadith which are habituation materials. Then proceed with the core activity here the teacher delivers learning materials using learning media made from natural or used materials. Today's theme is My Environment, My Home Sub-theme, Household Appliances/Washbasket Functions. The teacher shows a picture of a wastebasket and then explains the function of the wastebasket. Then the teacher gives an example of collage work with a picture of a waste basket collated with tree branches. After that the teacher gives a worksheet to the child so that the child does a collage with tree branches on the image of the waste basket. After the children finished working, the teacher asked the children what the function of the waste basket was. The students mention the function of the waste basket. This is where the teacher's ability to convey material is required so that the learning process can run well."

From the results of the assessment and supported by the results of interviews and observations made at Raudhatul Athfal Munawwarah Medan, it can be said that the learning process carried out by teachers using learning media made from natural and used materials has been going well. Teachers must be able to carry out their duties as educators who are required to have pedagogic competence, namely the ability to manage student learning which includes understanding students, designing and implementing learning, evaluating learning outcomes and developing students to actualize their various potentials.

It is described in detail in the Government Regulation of the Republic of Indonesia Number 74 of 2008 concerning teachers, article 3 paragraph (4) "pedagogic competence is the ability of teachers to manage student learning which at least includes: (1) understanding of educational insights or foundations, (2) understanding of students, (3) developing curriculum or syllabus, (4) designing learning, (5) implementing educational and dialogical learning, (6) evaluating learning outcomes, (7) developing students to actualize their various potentials. ${ }^{47}$

\footnotetext{
46 Hasil wawancara dengan Ibu Mardiah, Guru Kelas di RA Munawwarah, tanggal 17 November 2020.

${ }^{47}$ Ali Mudlofir, Pendidik Profesional (Depok: Rajawali Pers, 2013), 75.
} 


\section{CONCLUSION}

Based on the findings and explanations above, it can be concluded that (1) the ability of teachers is fairly good in designing teaching materials sourced from natural and used materials, this is evidenced by the readiness of teacher learning plans; (2) the implementation of learning takes place effectively, marked by the suitability of the plans that have been made previously with the learning implementation process, as well as the process of learning activities using natural materials and used materials, starting from initial activities, core activities to closing activities; and (3) the cognitive competence of students at RA Munawwarah Medan is increasing well, marked by the child's ability to mention numbers, know the concept of numbers, be able to sort objects from smallest to largest, group objects according to type and color, and mention the function of an object.

\section{REFERENCES}

Aqib, Zainal. Model-model Media dan Strategi Pembelajaran Kontekstual Inovatif. Bandung: Yrama Widya, 2017.

Arikunto, Suharsimi. Prosedur Penelitian Suatu Pendekatan Praktik. Jakarta: Rineka Cipta, 2007.

Asmawati, Luluk. Perencanaan Pembelajaran PAUD. Bandung: Remaja Rosdakarya, 2014.

Assingkily, Muhammad Shaleh. Penelitian Tindakan Kelas (Meneliti dan Membenabi Pendidikan dari Kelas). Medan: CV. Pusdikra Mitra Jaya, 2021.

Bungin, Burhan. Metodologi Penelitian Kuantitatif. Jakarta: Prenada Media Group, 2005.

Danim, Sudarwan. Menjadi Peneliti Kualitatif. Bandung: Pustaka Setia, 2002.

Hildayani, Rini. Psikologi Perkembangan Anak. Jakarta: Universitas Terbuka, 2004.

Karwono. Belajar dan Pembelajaran Serta Pemanfaatan Sumber Belajar, edisi Revisi. Jakarta: PT. Rajagrafindo Persada, 2012.

Khadijah. Media Pembelajaran Anak Usia Dini. Medan: Perdana Publishing, 2015.

Miles, Matthew B. \& A Michel Huberman. Analisis Data Kualitatif tentang Metode-metode Baru, Terj. Tjetjep Rohidi. Jakarta: Universitas Indonesia Press, 2009.

Mudlofir, Ali. Pendidik Profesional. Depok: Rajawali Pers, 2013.

Murni, Wahid. Cara Mudah Menulis Proposal dan Laporan Penelitian Lapangan Pendekatan Kualitatif, Skripsi, Tesis, dan Disertasi. Malang: UM Press, 2008.

Mutiah, Diana. Psikologi Bermain Anak Usia Dini. Jakarta: Prenada Media Group, 2010.

Nasution, S. Metodologi Penelitian Naturalistik Kualitatif. Bandung: Tarsito, 1996.

Nurhidayah, et.al. Penerapan Metode Bercerita Berbantuan Media Papan Flanel untuk Meningkatkan Kemampuan Berbicara di TK Kamila Singaraja, Jurnal PAUD Universitas Pendidikan Ganesha, 4(1), 2016. https://ejournal.undiksha.ac.id/index.php/JJPAUD/article/view/7806.

Sautele, Eleanor, et.al. Resielence, Self Regulation and Cognitive Ability, Relevant to Teacher Selection, Journal of Teacher Education, 40(1), 2015. https://search.informit.org/doi/abs/10.3316/ielapa.080852592705061.

Siswoyo, Dwi. Ilmu Pendidikan. Yogyakarta: UNY Press, 2013.

Sofia, Hartati. Perkembangan Belajar pada Anak Usia Dini. Jakarta: Departemen Pendidikan Nasional, 2012.

Sugiyono. Metodologi Penelitian Kuantitatif, Kualitatif \& RnD. Bandung: Alfabeta, 2016.

Sujarwo. Pengembangan Media Pembelajaran PAUD. Yogyakarta: SKB, 2008.

Suyadi, et.al. Konsep Dasar PAUD. Bandung: Remaja Rosdakarya, 2013.

Tashakkori, Abbas \& Charles Teddie. Mixed Methodology: Mengkombinasikan Pendekatan Kualitatif dan Kuantitatif. Jakarta: Pustaka Pelajar, 2010. 
Khairuni Siregar, et.al.

Zaman, Badru \& Cucu Eliyawati. Bahan Ajar Pendidikan Profesi Guru (PPG): Media Pembelajaran Anak Usia Dini. Bandung: Universitas Pendidikan Indonesia, 2010. 